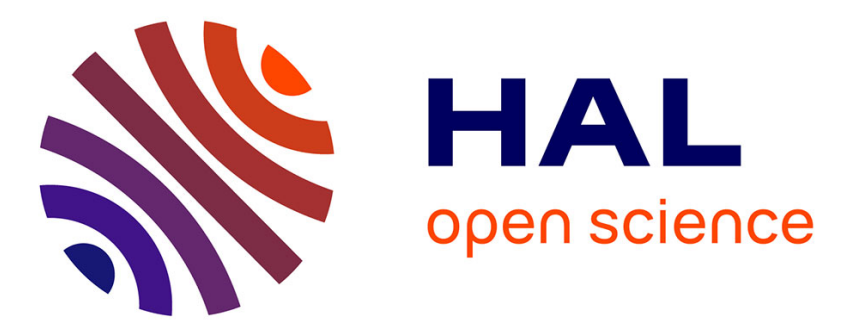

\title{
Open Access, Privacy, and Human Rights: A Case Study on Ethics in Library and Information Sciences Education
}

Joachim Schöpfel

\section{To cite this version:}

Joachim Schöpfel. Open Access, Privacy, and Human Rights: A Case Study on Ethics in Library and Information Sciences Education. Ursula Gorham; Natalie Greene Taylor; Paul T. Jaeger. Perspectives on Libraries as Institutions of Human Rights and Social Justice, 41, Emerald, pp.349 - 371, 2016, Advances in Librarianship, 10.1108/S0065-283020160000041015 . hal-01408444

\section{HAL Id: hal-01408444 \\ https://hal.univ-lille.fr/hal-01408444}

Submitted on 4 Dec 2016

HAL is a multi-disciplinary open access archive for the deposit and dissemination of scientific research documents, whether they are published or not. The documents may come from teaching and research institutions in France or abroad, or from public or private research centers.
L'archive ouverte pluridisciplinaire HAL, est destinée au dépôt et à la diffusion de documents scientifiques de niveau recherche, publiés ou non, émanant des établissements d'enseignement et de recherche français ou étrangers, des laboratoires publics ou privés.

\section{(c)(1)}

Distributed under a Creative Commons Attribution| 4.0 International License 


\section{Open Access, Privacy and Human Rights. A Case Study on Ethics in Library and Information Sciences Education \\ Joachim Schöpfel}

Acknowledgment to my MA and BA students in library and information sciences at the University of Lille (France), for their rich and interesting ideas and comments on ethics in librarianship.

\section{Structured Abstract:}

Purpose: How do students comment on ethical principles, which principles are important for their awareness of librarianship, how do they understand the relevance of human rights for their future work?

Approach: The case study presents the results of a lecture on information rights and ethics with 50 Master students in library and information sciences at the University of Lille (France) in 2014-2015. Students were asked to comment on the core principles of the IFLA Code of Ethics.

Findings: The students see the library as a privileged space of access to information, where the librarian takes on the function of a guardian of this specific individual freedom - a highly political role and task. This opinion is part of a general commitment to open access and free flowing resources on Internet. They emphasize the social responsibility towards the society as a whole but most of all towards the individual patron as a real person, member of a cultural community, a social class or an ethnic group. With regards to Human Rights, the students interpret the IFLA Code mainly as a code of civil, political and critical responsibility to endorse the universal right of freedom of expression. They see a major conflict between ethics and policy. The findings are followed by some recommendations for further development of LIS education, including internship, transversality, focus on conflicts and the students' cognitive dissonance and teaching of social skills, in terms of work-based solidarity and collective choices.

Originality: The paper is qualitative research based on empirical data from a French LIS Master program.

\section{Keywords: Ethics, human rights, library and information sciences, education, IFLA Code of Ethics}

\section{Article Classification: Case study}

\section{Introduction}

Librarianship has a strong ethical dimension. "What libraries symbolize is society's best idea about itself" (Conner 2014, p.148). Ideas may never die but every generation must earn and win them and make them its own. What is true in general applies also to libraries. Their values and ethics have a long tradition, and several papers have been written about the values at the very heart of librarianship. Gorman (2000) for instance identified eight guiding 
principles and values of librarianship which form a kind of core ethics, like stewardship, intellectual freedom, literacy and learning, privacy and democracy.

However, not all of Gorman's "enduring values" appear to be shared by librarians from different countries and cultures. Foster \& McMenemy (2013) evaluated 36 codes of ethics and revealed that only five values are common to most countries, i.e. service, privacy, equity of access to recorded knowledge and information, stewardship and intellectual freedom. But even so, these core principles are not self-evident, and privacy and democracy especially are subject to divergent interpretations, due to dissimilar legal, cultural and social environments. "Librarians and their associations have to be aware that their professional codes of ethics are neither unchangeable nor completely universal. Cultural differences and the difference in laws between countries need to be taken into consideration" (Valloton-Preisig 2014, p.213).

Paul Sturges made out some of these links between librarian ethics and historical context in a significant paper published in 2002. He showed how, because of political experience ("world events") like the war against Nazi Germany, the Cold War with Soviet Russia or McCarthyism, American librarians developed a solid commitment against censorship and in favour of freedom of access to information, with an absolute minimum of restrictions. "Librarians came to feel that it made more sense to respond to what users wanted to know, rather than to tell them what they should know" and that they should above all provide "uncensored, 'objective' information" (Sturges 2002, p.210). Even if the "world events" of the younger generations of librarians are different from those described by Paul Sturges, the commitment to freedom of information remains a crucial value of librarianship, beyond discipline-specific knowledge.

We wanted to learn more about the professional ethics of younger librarians and library students. Convinced that ethical thinking and standards are not only the results of personal experience but also of formal education, we wondered how French LIS students in 2014 consider the fundamental principles of librarianship, such as social justice, equity of access to information and intellectual freedom. How do they comment on values ${ }^{1}$, which are the principles that are important for their awareness of their vocational role, and how do they understand the relevance of universal human rights for their future work?

Library students are concerned by these generic skills in two ways: as young citizens and as future professionals. In France, human rights are part of the constitution and the historical and political heritage, and all children and youths learn about revolution, freedom and human rights during their primary and high school education. More recently, the French government required that ethics and deontology be part of all academic undergraduate and graduate programs. Our Lille Master curriculum ${ }^{2}$ introduces ethics as a knowledge area together with information rights and other legal aspects. The lectures include an introduction to intellectual property, licensing, privacy, patents, public tender and contracts, together with an overview of professional values and ethics. As in many LIS programs (see Gerolimos 2009), ethics and social responsibility unlike marketing, web site creation or metadata are not taught in a specific course or as explicit main skills, but as generic or social skills, based on the IFLA Code of Ethics ${ }^{3}$, personal experience and awareness, and knowledge of law and court decisions.

Sometimes, the debate on LIS education programs puts the focus on information literacy and technological know-how and neglects the normative dimension of "value-based skills" and ethical awareness (Vaagan 2003). Our intention was to learn more about the LIS students' ethical concerns and standards, with two objectives: to improve our Lille Master program in

\footnotetext{
${ }^{1}$ Values as defined by Hallam (2007): "the beliefs that guide our decision about which problems to solve, the methods to choose and how evidence is evaluated" (p.329).

${ }^{2}$ Master "Information and Documentation", see https://www.univ-lille3.fr/ufr-deccid/sid/formation/

${ }^{3}$ http://www.ifla.org/faife/professional-codes-of-ethics-for-librarians\#iflacodeofethics
} 
particular and to contribute to the discussion about LIS education, info ethics and values in general.

\section{Methodology}

Our sample consisted of 52 students from the University of Lille 3 (France), out of 55 students in the first year of our Master program. Between September and December 2014 they followed a lecture on information rights and ethics that is an obligatory part of the Master "Information and Documentation". Most students are from France but some 20\% are from foreign countries (Europe, Maghreb, Sub-Saharan Africa, China). Half of the students already have professional experience, often as teachers or information professionals. After the twoyear Master program, one part of these students will become public, high school or university librarians while others will work in public administration or in the corporate sector, in jobs related to documentation, web design and referencing, community management, economic intelligence, records management, database administration, knowledge organization etc. Few will stay on for a PhD scholarship.

As part of the coursework, they were asked to write a short dissertation (five to ten pages) on one of the six core sections or clauses of the IFLA Code they considered as important. They had two months to do this, and they could submit individual or group work. The dissertation had to include at least three parts: an explanation of the selected clause, a real case (example) of how it applies, and a critical analysis of its limits and weaknesses.

All submitted copies were rated in the Master program. For the purpose of this case study, the copies were re-analysed with special attention to the following aspects:

- Which are the most important core principles of the IFLA Code of Ethics? Can we identify a specific profile of ethical awareness, or are ethics rather a matter of personal choice?

- Which are for these students "sensitive situations" in librarianship? Can we identify "critical examples" for the application of ethical principles in libraries and other information services?

- Do they mention human rights? In what way are they aware of human rights? How do they link the IFLA core principles to human rights? Where is their "focus of attention"?

- Where do they see limits and weaknesses of the IFLA code? Are they aware (and if so, in what way) of potential and real conflicts between ethics, human rights, laws and administrative rules, i.e. perceived limitations of ethical principles by universal rights, national law or professional regulations?

- And finally, do they take a critical stance towards the IFLA Code of Ethics? Are they aware of limits, problems, contradictions and so on?

This re-analysis was anonymous. It was conducted as a conceptual analysis with manual coding of the manifest content of the written papers (keywords, sets of words, expressions) in order to identify the dominant message and subject matter related to our questions within the text, with subsequent classification and transformation into descriptive statistics. The students were informed about this second analysis and were given the opportunity to discuss the results. Nota bene: the dissertations were written and submitted some weeks before the Paris attacks on the satirical magazine Charlie Hebdo and a kosher supermarket in January 2015. Re-analysis and discussion were done after the attacks.

Clause 1. Access to information

The core mission of librarians and other information workers is to ensure access to information for all for personal development, education, cultural enrichment, leisure, economic activity and informed participation in and enhancement of democracy. Librarians and other information workers reject the 
denial and restriction of access to information and ideas most particularly through censorship whether by states, governments, or religious or civil society institutions (...)

Clause 2. Responsibilities towards individuals and society

In order to promote inclusion and eradicate discrimination, librarians and other information workers ensure that the right of accessing information is not denied and that equitable services are provided for everyone whatever their age, citizenship, political belief, physical or mental ability, gender identity, heritage, education, income, immigration and asylum-seeking status, marital status, origin, race, religion or sexual orientation (...)

Clause 3. Privacy, secrecy and transparency

Librarians and other information workers respect personal privacy, and the protection of personal data, necessarily shared between individuals and institutions. The relationship between the library and the user is one of confidentiality and librarians and other information workers will take appropriate measures to ensure that user data is not shared beyond the original transaction. Librarians and other information workers support and participate in transparency so that the workings of government, administration and business are opened to the scrutiny of the general public. They also recognise that it is in the public interest that misconduct, corruption and crime be exposed by what constitute breaches of confidentiality by so-called 'whistleblowers'.

Clause 4. Open access and intellectual property

Librarians and other information workers' interest is to provide the best possible access for library users to information and ideas in any media or format. This includes support for the principles of open access, open source, and open licenses. Librarians and other information workers aim to provide fair, swift, economical and effective access to information for users. Librarians and other information workers have a professional duty to advocate for exceptions and limitations to copyright restrictions for libraries. Librarians and other information workers are partners of authors, publishers and other creators of copyright protected works. Librarians and other information workers recognise the intellectual property right of authors and other creators and will seek to ensure that their rights are respected (...)

Clause 5. Neutrality, personal integrity and professional skills

Librarians and other information workers are strictly committed to neutrality and an unbiased stance regarding collection, access and service. Neutrality results in the most balanced collection and the most balanced access to information achievable. Librarians and other information workers define and publish their policies for selection, organisation, preservation, provision, and dissemination of information. Librarians and other information workers distinguish between their personal convictions and professional duties. They do not advance private interests or personal beliefs at the expense of neutrality (...)

Clause 6. Colleague and employer/employee relationship

Librarians and other information workers treat each other with fairness and respect. Librarians and other information workers oppose discrimination in any aspect of employment because of age, citizenship, political belief, physical or mental ability, gender, marital status, origin, race, religion or sexual orientation. Librarians and other information workers promote equal payment and benefits for men and women holding comparable jobs. Librarians and other information workers share their professional experience with colleagues and they help and guide new professionals to enter the 
professional community and develop their skills. They contribute to the activities of their professional association and participate in research and publication on professional matters (...)

Table 1: IFLA Code of Ethics (shortened version)

\section{Results}

The following section presents the results in the order of the leading questions (see above) and related to the six clauses from the IFLA Code of Ethics (see Table 1 for a shortened version of the IFLA Code). Whenever possible and useful, quotations are made from the students' dissertations (in italics) and translated into English (by the author).

\subsection{Concern and awareness}

Which are the most important core principles of the IFLA Code of Ethics? Can we identify a specific profile of ethical awareness, or are ethics rather a matter of personal choice? The following figure reveals that nearly $60 \%$ of the students are most strongly committed to access-related principles, e.g. access to information (1) and intellectual property (2) (Figure $1)$.

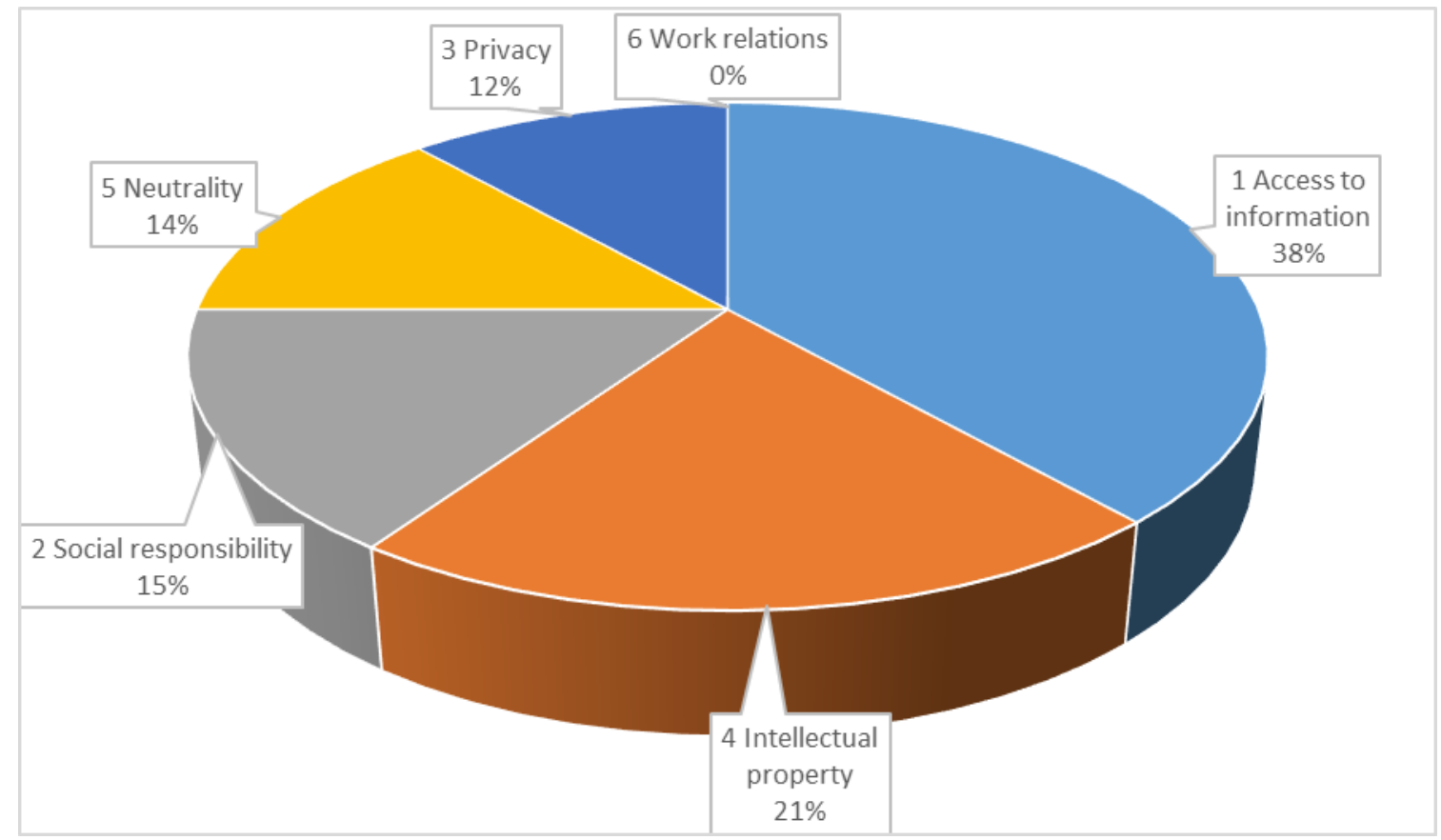

Figure 1: Choice of IFLA principles (with clause number and percentage, N=52)

\section{Access to information}

Clause 1 on access to information starts like this: "The core mission of librarians and other information workers is to ensure access to information for all for personal development, education, cultural enrichment, leisure, economic activity and informed participation in and enhancement of democracy." $38 \%$ of the students decided to work on this clause, while $21 \%$ opted for Clause 4 on open access and intellectual property. For all of them, the challenge is to guarantee unrestricted and uncensored access to all kinds of content and for all kinds of readers and library patrons. Some of them link Clause 1 to Ranganathan's five laws of library science (1931), in particular the right of each reader to get his/her book and the right of each book to find its reader. "Censorship is not compliant with the mediation of knowledge and personal growth." The library is seen (and praised) as a privileged space of access to 
information, where the librarian takes on the function of a guardian of this specific individual freedom - a highly political role and task.

\section{Open access and intellectual property}

"Librarians and other information workers' interest is to provide the best possible access for library users to information and ideas in any media or format. This includes support for the principles of open access, open source, and open licenses." This is the first sentence of Clause 4 of the IFLA Code. Those students working on this clause $(21 \%)$ insisted above all on the gratis and "libre" access to online resources. The protection of intellectual property rights is seen as an obstacle or constraint for the delivery of information rather than as a necessary and useful condition to respect and to enforce. In their own words:

"The goal of information professionals is to make all kinds of data accessible."

"One of the most important tasks of the librarian is to promote availability of information."

"The library staff cannot act on the author's intellectual property as they want (yet) each user has the right to get the same quantity and quality of information as anyone else."

For the students, the primary function of the librarian is to help and support the patron's information needs and rights, not to make compromises between those needs and intellectual property issues. Their viewpoint has more to do with advocacy than with professionalism and law.

\section{Responsibilities towards individuals and society}

$15 \%$ of the other students share this opinion of the political character of the librarian's role, as they emphasize his/her social responsibility (Clause 2) towards the society as a whole but moreover and most of all towards the individual patron as a real person, member of a cultural community, a social class or an ethnic group.

This Clause 2 requires that "in order to promote inclusion and eradicate discrimination, librarians and other information workers ensure that the right of accessing information is not denied and that equitable services are provided for everyone whatever their age, citizenship, political belief, physical or mental ability, gender identity, heritage, education, income, immigration and asylum-seeking status, marital status, origin, race, religion or sexual orientation." The students reformulate it in their own way:

"The library is a social place for meeting and is open to the world."

"All persons entering a library have the same rights and obligations."

Yet, students are aware that the library not only as an institution, but also as a physical place with rules and contents may exert a discriminatory function between different social and cultural groups. They highlight the role of the librarian as a facilitator and mediator, as opposed to being a barrier or "obstacle" between the user/patron and information.

"The library should be attractive... a place of intermingling, of diversity, of intergeneration." Should be - but they are aware, too, that often his goal is not achieved.

\section{Neutrality, personal integrity and professional skills}

Nearly as many students (14\%) selected for their dissertation Clause 5 of the IFLA Code on neutrality, personal integrity and professional skills which says that "librarians and other information workers are strictly committed to neutrality and an unbiased stance regarding collection, access and service. Neutrality results in the most balanced collection and the most balanced access to information achievable."

Students are aware that librarians are simply "people like others", with personal convictions, preferences and values that may interfere with the neutrality principle. Yet, some are conscious, too, of what they call the "dominant ideology":

"Ideology often represents the cultural dimension of a social institution or power system (...) generally it is diffuse and omnipresent, and often more or less invisible for those parts of the institution or system." 
Students discuss neutrality and integrity in terms of "custodianship" for the nondiscrimination and respect of the patrons' rights and freedom of access to information they need and require, be they in conflict with the librarians' personal convictions or institutional values or not.

\section{Privacy, secrecy and transparency}

"Librarians and other information workers respect personal privacy, and the protection of personal data, necessarily shared between individuals and institutions." This is how Clause 3 starts. Paul Sturges (2002) considered privacy as "a crucial concept in modern librarianship. By protecting the user's privacy, librarians do at least offer some mental space in which it is possible to maintain individuality" (p.211). Surprisingly, at least here in our study privacy issues are not a major concern. Only $12 \%$ of the students worked on Clause 3. And even more surprising, their main motivation appears to be transparency and not privacy. Those students who chose Clause 3 for their homework mainly wrote on the potential or real role of librarians as whistle-blowers and support for campaigns against corruption and political affairs while privacy concerns such as protection of personal data or private sphere are mentioned less often.

\section{Colleague and employer/employee relationship}

No student selected Clause 6 of the IFLA Code, on colleagues and employer/employee relationships. "Librarians and other information workers treat each other with fairness and respect." This sentence from Clause 6 does not seem to attract much attention. Probably, they do not consider social relations and behaviours in the workplace as a major issue of ethics and deontology. For some of them, relationship at work may be a matter of personal social skills, group dynamics and work conditions, and kind of "out of scope" regarding ethics. It may also be that many students are simply lacking in job experience.

\subsection{Interest and experience}

The students were asked to provide examples for their discussion on the selected IFLA clause. Which are for these students "sensitive situations", i.e. professional situations that require value-based decisions and not only application of professional rules and routines? Can we identify "critical examples" for the application of ethical principles in libraries and other information services? First of all, as we stated before, all students are not primarily interested in librarianship but will work as information officers in public administration or in the corporate sector. So it may not be surprising that nearly one third mention more or less general concerns, not directly related to the reality of librarianship (Figure 2). 


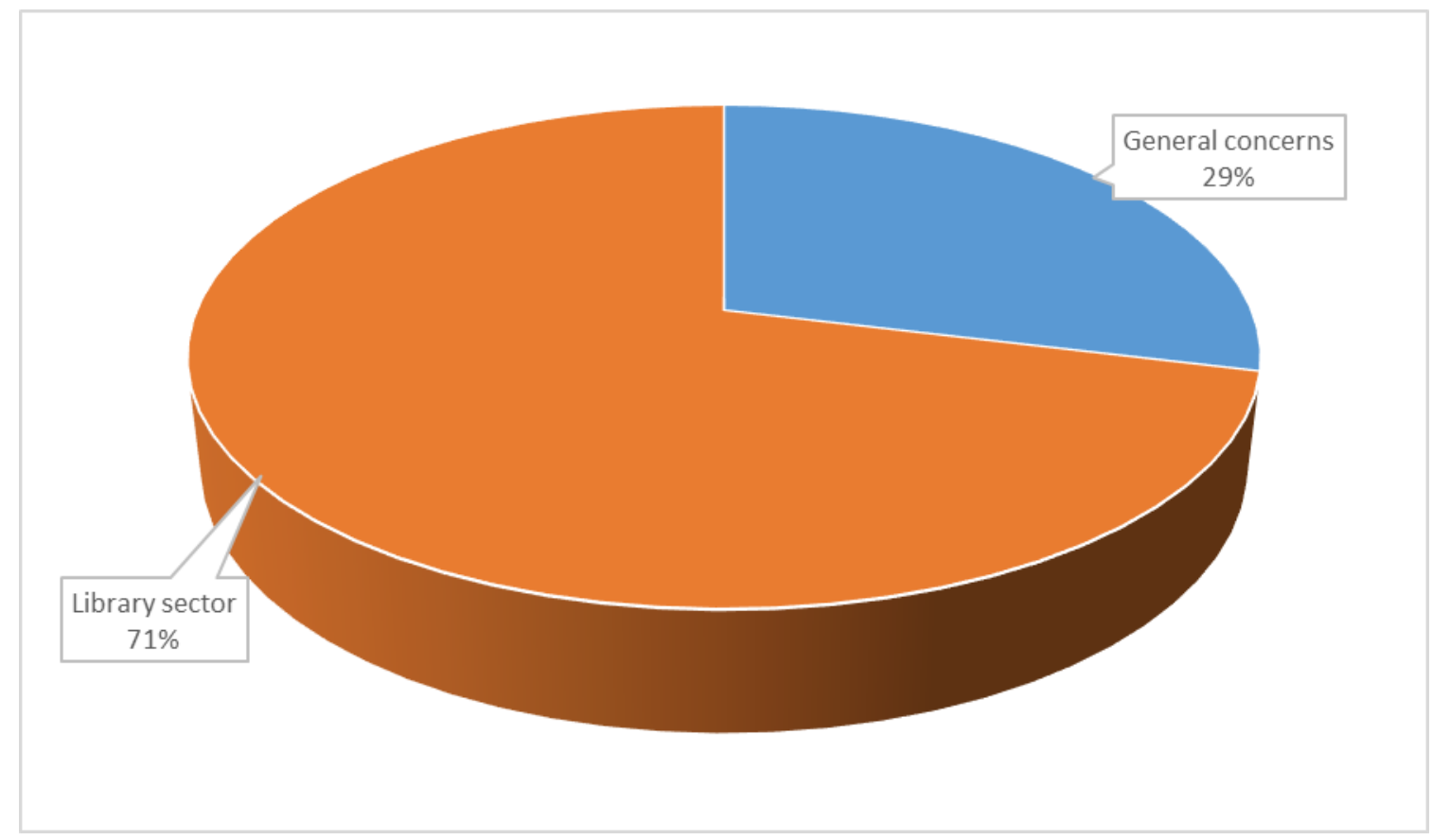

Figure 2: Fields of awareness $(\mathrm{N}=52)$

Nearly all of the related examples and "critical cases" are from France, sometimes from their own experiences, sometimes from newspapers or Internet or from historical knowledge. Some students report "fait divers"/current affairs from other countries, in particular the United States, China, the UK and Arab countries. For most of the students, speaking about libraries means speaking about public libraries, including what is called "médiathèques" in France, i.e. local public multimedia libraries with music and video collections and Internet facilities. Nevertheless, $15 \%$ of the students share examples from academic libraries, and $6 \%$ report a problem from the French National Library. In the following, we will present some of the main arguments.

\section{Free access to information}

For many students, open access to information, non-discrimination and neutrality are part of the same concern. In the words of one student:

"Access to information is not to the goodwill either of the librarian or of his/her superior or of the government."

This opinion is part of a general commitment to open access and free flowing resources especially on Internet. For instance, they are in favour of the sharing of open content, through initiatives like SPARC and open licences like Creative Commons, and they are against any barriers, like digital rights management devices (DRM). They are also in favour of open repositories for the preservation and dissemination of scientific publications and research results.

One example is a French collaborative platform for the sharing of music specifically designed for use in public libraries ${ }^{4}$. What is more, according to their argument, this dissemination of "free music" under open licences (Creative Commons) in public libraries foster creation and cultural diversity, which is a central argument for French cultural policy:

"Moreover, music librarians appear to contribute to artistic creation through the dissemination of their works among the libraries ' public."

\footnotetext{
${ }^{4}$ See http://www.acim.asso.fr/ziklibrenbib
} 
Others are aware of abusive application and claiming of intellectual property rights, especially regarding cultural content in the public domain (copyfraud ${ }^{5}$ ). Here, one group of students brings up a recent joint venture of the French National Library for the digitization of heritage material (an old book collection of French literature), including exclusive rights for the exploitation of the digitized collection for ten years. For the students, this is in conflict with the principle of open access:

"Culture is assimilated to a commercial commodity (where) the user becomes a consumer instead of being an active player (...) Helshe should not have to rent but own the public domain."

Another sensitive case is the free-of-charge access to the library. For many students, usage of library resources should be free. Their argument: registration fees limit access and contribute to discrimination. One example: the public library of the French town Tours decided on free registration in 2001 and since then has increased its readership from 25,000 to 35,000, a figure which is equivalent to $28 \%$ of the local population. But they are conscious, too, that the libraries' options depend at least partly on local policy and in particular, on public funding and budget cuts - an argument we will find again in the context of neutrality and transparency.

Neutrality and non-discrimination

Regarding neutrality and non-discrimination, we can distinguish different levels in the arguments and examples, some of them close to open access. For instance, students talk about a recent project of the public library of Roubaix, another French town near Lille with many immigrants and much unemployment. The library created free "civil digital workplaces" in order to fight the digital divide and to support the citizens' equality with regards to information technology. Other examples concern actions in favour accessibility to the library for physically disabled people.

A totally different problem, very present in the minds of students, is the political dependency of public libraries. Political dependency includes local authorities as well as media and public opinion. Three examples:

During the public debate in France last year (2014) on gay marriage and the adoption of children, a strong conservative, pro-family and anti-gay campaign lobbied on the Web and via social media for the weeding out of books on gender studies and homosexuality in public libraries, employing a kind of media-based censorship to prohibit access to information on gender equality, gays, lesbians etc.

"Some people went to public libraries, exerted pressure on librarians and asked them to justify their acquisition policy. They also inspected the library holdings, with a particular obsession for the youth section, and required to weed out all books not compliant with the morals they claimed to incarnate."

A second, often cited example is the cultural policy after the victory of the right-wing party Front National in various French towns, in local elections a couple of years ago. After their victory, one of their first actions was to call for the "ideological weeding" of the public holdings.

This recent case of political dependency reminds some students of what was called the "journal war" during the years after World War II, when local authorities decided on the libraries' subscriptions to left or right journals and magazines according to their own political orientation.

Other students remember the German occupation of France (1940-1944) when the Nazis confiscated about 700,000 books in French public and private libraries and censored more than 1,000 publications.

\footnotetext{
${ }^{5}$ See Mazzone (2006).
} 
Two completely different examples appeal to professional consciousness. Here the students ask questions rather than express their opinion.

Should librarians handle Hitler's Mein Kampf just like any other book? Some hide the book somewhere in the library store but lend it on demand while others limit the reservation to onsite consultation in the reading room. Whether they decide to lend this book or not, are they acting "for freedom of expression or against racist propaganda"? Is this censorship?

One student conducted a survey on the sociology of the librarian's work. She reports that librarians do not want to buy everything their patrons ask for, especially when they ask for sentimental novels or pulp fiction, and she adds that "this poses a problem because the user can feel illegitimate in his/her reading practices. However, can librarians judge the legitimacy of their patrons' reading behaviour?"

\section{Privacy and transparency}

We also mentioned above that privacy does not seem to be the most important issue in our sample. Those students who deal with this clause express concern with section 215 of the USA PATRIOT Act on access to records and other items under the Foreign Intelligence Surveillance Act, including the possibility to have access to data collected and stored by public and scientific libraries. Again, the students' question is which role a library should play - protection of the patron-citizen against authorities, or support of public action against crime and terrorism? Should a librarian alert security agencies because of suspicious information behaviour? ${ }^{6}$ And in fact, what is suspicious information behaviour - reading about Islamic religion and history, an interest for specific fields of chemistry? At least some students appear to know the US debate on the PATRIOT Act and libraries very well, in particular through conferences and publications of the American Library Association.

Also, students do not cite many real cases regarding transparency. The main opinion is that a policy of open data will foster democracy and increase freedom of information and transparency. One student adds that librarians should rather inform people about their civil rights than do "whistleblowing" because they are either not able or not willing to do this, again because of political dependency.

\subsection{Human rights}

One part of the IFLA Code of Ethics guiding principles is deeply rooted in universal human rights. In particular, intellectual freedom and equity of access to knowledge and information are part of the right to freedom of expression recognized as a human right under Article 19 of the Universal Declaration of Human Rights, including freedom to seek, receive and impart information and ideas of all kinds. In what way are the students aware of human rights? How do they link the IFLA core principles to human rights? Where is their "focus of attention"?

As mentioned above, human rights are part of French history, constitution and school education. So it is not surprising that more than half (58\%) of them spontaneously mentioned the Declaration of Human Rights in relationship to the IFLA Code of Ethics. What is more surprising is the way they establish the connection (Table 2).

\begin{tabular}{|l|c|c|}
\cline { 2 - 3 } \multicolumn{1}{c|}{} & yes & no \\
\hline 1 Access to information & 16 & 4 \\
\hline 2 Social responsibility & 4 & 4 \\
\hline 3 Privacy & 3 & 3 \\
\hline 4 Intellectual property & 3 & 8 \\
\hline 5 Neutrality & 4 & 3 \\
\hline 6 Work relations & 0 & 0 \\
\hline
\end{tabular}

\footnotetext{
${ }^{6}$ The same kinds of questions as in the handbook on ethical practice by McMenemy et al. (2007).
} 
Table 2: Linking IFLA Code clauses to human rights $(\mathrm{N}=52)$

The Master students interpret the IFLA Code mainly as a code of civil, political and critical responsibility to endorse the universal right of freedom of expression. Most of the students (16 of 20) who wrote about Clause 1 mentioned human rights. In their own words:

"Information is the oxygen of democracy."

"One cannot be a free citizen in a society of information without the legitimate right of free circulation of ideas which is a guarantee of democracy."

Clearly, Clause 1 is dominant in their representation of human rights. Other clauses, especially Clause 2, are more easily related to national law, e.g. the French legislation on nondiscrimination. Here, the link to human rights is indirect, via the French constitution and legal system, both based on the Declaration of Fundamental Human Rights. Two other examples:

- the link students make between neutrality (Clause 5) and secularism ("laicité"), the principle of the separation of governmental and religious institutions and persons that is part of the fundamentals of the French Republic since more than a hundred years;

- and the connection between the French government's policy in favour of open data and the campaign against corruption: "Open data is good for transparency."

Perhaps more surprising and unexpected is the relatively low importance of open access and the protection of intellectual property (Clause 5) regarding human rights. Only few students (3 of 11) who selected this Clause mentioned human rights. According to the students' argumentation, they consider these topics more as a political or institutional affair, as a kind of application of the fundamental principle of freedom of expression and information and not as fundamental principles by themselves.

3.4. Conflict

Are they aware (and if so, in what way) of potential and real conflicts between ethics, human rights, laws and administrative rules? They are, in different ways and on different levels.

"The right of access to information can enter into conflict with other rights, e.g. privacy, public order, protection of health and morality, territorial integrity, public security, crime prevention: the freedom of information does not cover every kind of information."

In compliance with their choice of examples and critical situations, the major conflict they see is between ethics and policy. Public libraries are part of local administration and placed under local authority. Librarians will have problems if they apply the ethical obligation and denounce corruption of their hierarchy. Some students recalled that according to the global civil society organisation "Transparency International", the "absence of legal protection of whistle-blowers in the public sector is a French paradox".

"Un upright public agent can lose everything, his job and his future."

Often, this conflict is seen above all as a problem with the local authority (mayor, town council, local delegates...), not with the State or the French government.

"The public librarian is both a public officer representing the State and its missions and an employee of a local authority. How does he/she accomplish his/her public mission if the local authority imposes opposite orders?"

Local policy and budget cuts, especially in times of public financial crises (austerity), can impact freedom to information and neutrality and create a kind of censorship:

"Librarians cannot buy everything they want, they have to make choices (...) It is difficult to hide behind the neutrality principle when making purchase choices."

"Today's censorship is of a financial nature."

The local conflict may also include lobbies, local communities, public opinion and local media. Officially, French public libraries are more or less autonomous, in particular for 
decisions on their acquisition policy but there is no law or decree to protect this cultural autonomy.

"Yet, most of the pressures on libraries are not legal (legitimate) but based on local usage, a mix of professional and political know-how, fears, conviction and financial pressure."

Even if local conflicts prevail, some students bring to mind the fact that governmental censorship is not only a problem for foreign countries but also for France, and they recall that for instance during the Algerian war (1954-1962) critical books were censored by the French State.

Privacy issues are another source of potential conflict with ethics, on three levels:

- Local surveillance: conflict between protection of privacy and surveillance in the library by security guards and/or camera monitoring.

- Library values: conflict between privacy and freedom of expression and the library's goals and "raison d'être". Three students report the case of a patron who requested a copy of anti-Semitic material at the library of the Alliance Israélite Universelle (AIU) in Paris. The librarian checked the identity of the patron and discovered that he was an active right-wing extremist. Should she do so? And then, should she satisfy the request or not? Is the respect for the library's fundamental values (here: the respect for Jewish history, including the Shoah) more important than the respect for the patron's right of expression and information?

- External interests: conflict between privacy and national laws and/or commercial interests. Libraries need some personal data on their patrons for their functioning but must be careful with the French privacy law ("Informatique et Liberté"), including those data they collect and store on information needs and behaviour. These data should remain confidential and be stored in a secure way, without disclosure to corporate societies, governmental agencies or other patrons.

In their own words:

"Privacy is a matter of data and also of usage."

"Searching for documents about specific topics provide information on the patron's interest subject to protection of privacy, e.g. on religion, travel destinations, political preference etc." A last field of potential conflict is intellectual property, i.e. the conflict between the legal constraints and obligations and the ethics of freedom of information and open access, highly valued by students. Students express in quite a similar way what Tomas Lipinski stated some years ago as follows: "ownership or control rights often conflict with other rights such as access to information, privacy, or a general sense of free speech" (2012).

\subsection{Criticisms and limits}

Our last question was: do students take a critical stance towards the IFLA Code of Ethics? Our analysis reveals that less than the half do so and are aware of different limits, problems and contradictions of ethics regarding librarianship.

Even if we cannot speak of a dominant opinion, the problem students mentioned most often were financial limits: the financial crisis in the French public administration not only limits the acquisition policy but also pushes institutions to consider cultural goods (like collections) as assets or commodities that can be valorised, i.e. transformed into money. In the same context, the lack of documents in Braille and foreign languages can be considered as not being respectful of minorities.

Other problems:

- Cultural limits: books are symbols of "legitimate culture" and can be a factor of discrimination, especially for young people from poor suburban areas, already in conflict with public institutions.

- Technological limits: Internet makes it difficult to protect authors' and publishers' rights. 
- Social limits: freedom of information does not eradicate the digital divide in society, i.e. the different levels of information literacy. Some students claim for positive discrimination instead of non-discrimination, i.e. specific information services and mediation for groups with special needs.

- Political limits: should full veils be admitted in the library because of the principle of non-discrimination? Today, they are prohibited because of the interdiction of full veil in public spaces. Another aspect is superior interest of the State and political dependency, as already cited above: "Can the libraries that are created and funded by the government really promote documents that the government has censored?"

- Psychological limits: some students think that the principle of neutrality is wishful thinking because all people, professionals or not, have their personal opinions and convictions. "The belief that one can be neutralist is an illusion." They suggest that instead of pursuing this illusion of neutrality, librarians should focus on verified information and discard propaganda or ideology, and they should communicate about their acquisition policy, justify and discuss choices they had to make in order to contribute to transparency of public action.

Main findings from the survey

The students see the library as a privileged space of access to information, where the librarian takes on the function of a guardian of this specific individual freedom - a highly political role and task.

For them, the primary function of the librarian is to help and support the patron's information needs and rights, not to make compromises between those needs and intellectual property issues advocacy prevails on professionalism and law. Also, open access to information, non-discrimination and neutrality are considered as part of the same concern: "Access to information is not to the goodwill either of the librarian or of his/her superior or of the government." This opinion is part of a general commitment to open access and free flowing resources on Internet.

Students emphasize the social responsibility towards the society as a whole but most of all towards the individual patron as a real person, member of a cultural community, a social class or an ethnic group. They discuss neutrality and integrity in terms of "custodianship" for the non-discrimination and respect of the patrons' rights and freedom of access to information they need and require, be they in conflict with the librarians' personal convictions or institutional values or not.

With regards to Human Rights, the students interpret the IFLA Code mainly as a code of civil, political and critical responsibility to endorse the universal right of freedom of expression: "Information is the oxygen of democracy." - "One cannot be a free citizen in a society of information without the legitimate right of free circulation of ideas which is a guarantee of democracy."

They see a major conflict between ethics and policy. Public libraries are part of local administration and placed under local authority. Or instance, librarians will have problems if they apply the ethical obligation and denounce corruption of their hierarchy. They are aware that local policy and budget cuts, especially in times of public financial crises (austerity), can impact freedom to information and neutrality and create a kind of censorship.

Table 3: Main findings from the survey

\section{Discussion}

Main survey findings are summarized in Table 3. Because of the small sample size, we must be careful not to over-interpret the results. They are illustrative rather than representative. They tell us about students' attitudes and cognitions of ethical principles but we cannot 
generalize and conclude that French students (or all students) think and argue in the same way. Another reason to be careful is the students' decision making. We asked them to write about a clause they consider as important, and we analyze and interpret the results under this perspective. However, some of them may have had other motives for their choice. As the survey was conducted in a context of evaluation, some students may have opted for a clause they consider as rather uncomplicated and presenting fewer difficulties than others. Yet, in spite of these possible sources of bias, we think that two or three aspects merit further attention, in the particular French context and beyond national borders.

\subsection{Professional and/or citizen}

Most of our students are in the situation described by Carbo (2008), with little or no experience in library/librarianship and/or management. Their viewpoints mainly reflect political rather than professional attitudes. The information ethics they express are often derived from general concerns about access to information and less from professional experience. Two examples:

- Their attitudes towards intellectual property and their strong preference for open access. Regarding intellectual property rights, most of them do not share or support the policy of the French Ministry of Culture (in charge also of the library sector), and some of them do not even seem to understand it.

- Their neglect of work relationships. Obviously, they do not understand social relationships at work as part of ethical behaviour, contrary to relationships with patrons and the community.

Also, one part of the students question the value and the need of a Code of Ethics. Some of them ask if it is really necessary to have such a code and if it is not sufficient to trust the individual librarians to be able to judge in their intimate and personal conscience on issues of intellectual freedom, privacy etc., as any ordinary citizen aware of human rights. Freeman (1996) highlighted the interest of a "code of conduct" as a legitimization and a protection of the professional: "This requirement to work on ethical standards beyond the required expectations of the ordinary citizen (...) is a type of "legitimizing" of the profession by the public and the state. (Its purpose) is primarily one of protection: protection of the professional from external governance and policies, and protection of the client from malpractice and other harm" (p18). Paradoxically, our students are aware of these "external governance, malpractice and other harm" but they seem to rely on republican values, the State's missions and public opinion (media) rather than on ethics, laws and professional solidarity.

\subsection{Awareness and action}

Being aware of "external governance, malpractice and other harm" does not mean being able to act in an adequate, ethical way. Students are generally aware of critical situations and problems, and they seem to consider the library as a kind of cultural sanctuary or reserve in an environment of permanent or latent surveillance, discrimination, restricted access and censorship. Yet, some comments seem to indicate that they see themselves more in the role of observer or witness than as a stakeholder with an active share of responsibility. They know more or less what is right and what is wrong. But it is not sure whether they know, or how THEY would behave in a given situation. And very few students are as confident as this one who stated that "librarians are not alone. They can legitimately denounce illegal practices without being personally at risk."

\section{3. \#Je suis Charlie}

The "world events" of our generation are different from those described by Paul Sturges a couple of years ago. Our political experience is shaped by economic crises, terrorism and religious fundamentalism, political fanaticism, increasing state surveillance and ecological concerns. 
Some students cited the case of the cartoons published by the French magazine Charlie Hebdo. Their question was: should a library be careful and hide this kind of material because some patrons could be offended? For instance, should High School libraries be careful especially with Muslim students? Can these cartoons trigger and foster islamophobia, prejudice and conflicts among the school community?

As stated above, the dissertations were written weeks before the Paris attacks on the satirical magazine Charlie Hebdo and a kosher supermarket in January 2015. Their reaction after the Paris attacks, just like the reaction of scholars, librarians and most of the French citizens, confirmed the high valuation of freedom of expression in the French society. I asked them after the attacks if they would have changed their opinion about ethics. They seemed surprised at the question, and they answered that they would have replied exactly in the same way, even more so, in particular with regards to freedom of expression and open access to information. Obviously their commitment to these fundamental values had been reinforced by current political events, and they showed their civil engagement through the tag \#Je suis Charlie.

But some months later, the situation has already changed. Today, the public debate is on neutrality of Internet, surveillance of information behaviour, control of websites and platforms etc. Last year, the problem of surveillance, national security and privacy was seen (externalized) as a problem of the American society, because of the USA PATRIOT Act. Today, the problem has become French. It could be interesting to assess how these students and future librarians will (re)consider the same questions next year or so. The value of a library is also the value it represents. Which values do publicly funded libraries represent? Can these values be in opposition to the superior interest of the State, the society or the nation? In the given situation, it seems probable that the conflicts between ethics, values and laws will increase and not diminish.

\section{Suggestions}

Master students leave for at least five to six months on internship in libraries, web agencies, information services etc., and they are evaluated on technological skills, theoretical knowledge, social integration, project management and outcomes - why not on ethics and deontology and human rights?

Information ethics should not be taught as a limited "knowledge field", complementary to technological or organisational topics, but as a transversal approach to different domains and in different lectures.

Education on ethics should focus on conflicts and criticisms, on the students' cognitive dissonance with work reality, local authorities, communities, government etc. in order to help students to find their own solutions, mentally as well as behaviourally.

Perhaps ethics should not (only) be taught and discussed in terms of individual behaviour or "intimate convictions" but as social skills, in terms of work-based solidarity and collective choices.

Table 3: Suggestions

\section{Conclusion}

Our paper started with some general comments on ethics education in library and information sciences. The survey was part of a lecture on information ethics and laws with French Master students. The content analysis of the students' dissertations may not be representative, because of the relatively small sample size, and the results are not always consistent. But we hope they illustrate some specific features of French LIS students, such as the high valuation of freedom of expression and information and the civil (political) awareness of critical situations in the public libraries. On the basis of our results, the paper concludes with some 
suggestions for the debate on ethics in librarianship and for ethics education in LIS programs (see Table 3 for a summary).

In all, the students are aware of fundamental values and how to apply them to critical situations. What is missing, though, are practical skills and behavioural options. They can be taught through discussion of constructed or real cases (see McMenemy et al. 2007). But furthermore, they should be objects of "internship experiences, mentoring by knowledgeable professionals and managers, in-house training and other professional development opportunities" (Winston 2005, p.242), including modelling of best practices. For instance, our Master students leave for at least five to six months on internship in libraries, web agencies, information services etc., and they are evaluated on technological skills, theoretical knowledge, social integration, project management and outcomes. But never on ethics and deontology and human rights. This will be a matter for discussion with the educational team.

Another aspect is that information ethics should not be taught as a limited "knowledge field", complementary to other, technological or organisational topics, but as a transversal approach to different domains and in different lectures, on database administration as well as on knowledge management, information architecture, marketing or law. Students do not learn ethics as they learn XML or a foreign language. Ethics make sense when applied to concrete situations.

Education on ethics should focus on conflicts and criticisms, on the students' cognitive dissonance rather than on fundamental values. As said above, they are generally aware of these values but they are also aware of limits and conflicts with work reality, local authorities, communities, government etc. Teaching should focus on these conflicts in order to help students to find their own solutions, mentally as well as behaviourally - especially for the main conflicts between universal ethics and communitarian values, and between fundamental rights, local authorities and the security policy of the State.

The last aspect would be the focus on professional relationships. This was an aspect students largely neglected in our survey. Perhaps ethics should not (only) be taught and discussed in terms of individual behaviour or "intimate convictions" but as social skills, in terms of workbased solidarity and collective choices. The protective function of professional ethics (Freeman 1996) becomes a reality only as a shared, social behaviour, not as an individual attitude "alone against the world".

6. Bibliography

Carbo, T. (2008), "Ethics Education for Information Professionals", Journal of Library Administration, $\quad$ Vol. $47 \quad$ No. 3-4, pp. 5-25. Available at http://dx.doi.org/10.1080/01930820802186324

Conner, M. (2014), The New University Library: Four Case Studies, Chicago IL, American Library Association.

Foster, C. and McMenemy, D. (2012), "Do Librarians Have a Shared Set of Values? A Comparative Study of 36 Codes of Ethics Based on Gorman's Enduring Values", Journal of Librarianship and Information Science, Vol.44 No.4, pp.249-262, available at http://dx.doi.org/10.1177/0961000612448592

Freeman, M. (1996), "Living by the Code: Some Issues Surrounding a Code of Conduct for the LIS Profession", New Library World, Vol. 97 No. 5, pp. 17-21, available at http://dx.doi.org/10.1108/03074809610122872

Gerolimos, M. (2009), "Skills Developed through Library and Information Science Education", Library Review, Vol.58 No. 7, pp. 527-540. Available at http://dx.doi.org/10.1108/00242530910978217

Gorman, M. (2000), Our Enduring Values: Librarianship in the 21st Century, Chicago IL, American Library Association. 
Hallam, G. C. (2007), "Education for Library and Information Service", In Ferguson, S. (Ed.), Libraries in the Twenty-First Century: Charting New Directions in Information Services, Centre for Information Studies, Charles Sturt University, pp.311-336. Available at http://eprints.qut.edu.au/11674/1/11674.pdf

Lipinski, T. (2012), "Law vs. Ethics”, Journal of Information Ethics, Vol. 21, No. 2, pp. 71103.

Mazzone, J. (2006), “Copyfraud”, New York University Law Review, Vol. 81, pp. 1026-1100.

Available at http://papers.ssrn.com/sol3/papers.cfm?abstract_id=787244

McMenemy, D., Poulter, A. and Burton, P. F. (2007), A Handbook of Ethical Practice, Oxford, Chandos Publishing.

Ranganathan, S. R. (1931), The Five Laws of Library Science, London, Edward Goldstone.

Sturges, P. (2002), "Remember the Human: the First Rule of Netiquette, Librarians and the Internet", Online Information Review, Vol. 26, No. 3, pp. 209-216. Available at http://dx.doi.org/10.1108/14684520210432486

Vaagan, R. W. (2003), "LIS Education - Repackaging Infopreneurs or Promoting ValueBased Skills?", New Library World, Vol. 104 No. 4/5, pp. 156-163. Available at http://dx.doi.org/10.1108/03074800310475972

Vallotton-Preisig, A., Rösch, H. and Stückelberger, C. (2014), Ethical Dilemmas in the Information Society: How Codes of Ethics Help to Find Ethical Solutions. Papers from the IFLA/FAIFE Satellite Meeting 2014, Geneva, Globethics.net. Available at http://www.globethics.net/documents/4289936/13403236/GE_Global_11_web_final.pdf

Winston, M. (2005), "Ethical Leadership: Professional Challenges and the Role of LIS Education", New Library World, Vol. 106, No. 5/6, pp. 234-243. Available at http://dx.doi.org/10.1108/03074800510595841 